\title{
INTERAÇÃO, UTOPIA E A CONSTRUÇÃO DE UMA ESCOLA INCLUSIVA
}

\author{
Miria Gomes de OLIVEIRA*
}

- RESUMO: Neste artigo, retomamos o surgimento da instituição escolar no berço da sociedade capitalista ocidental e discutimos o lugar reservado às práticas de leitura e escrita na idealização de uma sociedade perfeita, a partir da discussão dos conceitos de utopia (MANNHEIM, 1976; RICOUER, 1989; BAKHTIN, 1988a, 1988b, 1997; SANTOS, 1995; OLIVEIRA, 2005), letramento (STREET, 2003; SIGNORINI, 1995a, 1995b; SOARES, 1998; COLLINS; BLOT, 2003). Nosso objetivo é revisitar esses conceitos, tendo em vista analisar interações entre professores e professores formadores que vivem mudanças implementadas pelo Programa Escola Plural, em andamento desde o ano de 1994, em Belo Horizonte. Dessa forma, explicitamos nosso entendimento de uma ética da interação na construção de uma escola inclusiva. Entendendo "inclusão na escola" como o conjunto de medidas que visam garantir educação a todos os cidadãos a quem esse direito foi historicamente negado ou denegado, recortamos falas e fragmentos de interações, ocorridas durante reuniões de formação. As análises revelam que nossos sujeitos ora reproduzem, ora resistem ao discurso liberal e ao "mundo lá fora", como costumam se referir às relações sociais. Revelam, também, as relações estabelecidas entre a forma como os professores percebem o papel da escolarização na vida futura dos estudantes e como idealizam (ou não) a sociedade em meio a esse processo.

- PALAVRAS-CHAVE: Interação. Utopia. Escola inclusiva.

\section{Introdução: o papel da interação na construção de uma escola inclusiva}

Neste artigo, discutiremos as relações entre práticas escolares, utopia e inclusão social a partir da análise de interações entre educadores e integrantes da secretaria municipal de ensino que realizam trabalho de formação na Rede Municipal de Ensino de Belo Horizonte.

A reforma educacional visada pela Escola Plural $(\mathrm{EP})^{1}$ nos faz pensar na possibilidade de notar, nas interações educadores/formadores, a relação específica entre o professor e a pólis - esta dimensão da cidade revelada pelos gregos que

* UFMG - Universidade Federal de Minas Gerais. Belo Horizonte - MG - Brasil. 31270-901- miriagomes@hotmail. com

1 Escola Plural é o projeto político pedagógico implantado pela Secretaria Municipal de Educação de Belo Horizonte durante o mandato do Movimento Frente Popular, movimento este que congregou forças de esquerda em sua gestão. Izabel Cristina A. S. Frade e Ceris Salete R. Silva (1998, p. 94) fazem uma análise da utilização dos cadernos da "Escola Plural" enquanto instrumento de formação continuada do professor, 
se opõe à haste enquanto mera construção material. Ao re-conhecermos a pólis, nos voltamos para a "alma" da cidade em que é discutida a construção em sua dimensão política e que coloca todos os cidadãos em pontos equidistantes com o poder.

Dentro desse cenário, a vida cívica depende do poder da palavra. A esfera pública da cidade é o espaço em que a atividade política depende da capacidade do cidadão de compartilhar significados. Trata-se de ver a cidade a partir de uma ética da interação. Mais do que o reconhecimento e o direito à fala de todos, interagir passa a ser o propósito primeiro dessa dimensão invisível da cidade. A interação é a esfera política que depende da presença constante do outro, ou melhor, estar só é estar incapacitado de agir (ARENDT, 1988).

Ainda que a escola seja vista como um mundo à parte, um mundo que prepara o aluno para este "mundo lá fora", na visão dos professores as tentativas de considerar o alcance ou extensão das habilidades e do conhecimento adquirido na escola resvalam em seu uso na sociedade. Na maioria das vezes, essas considerações se tornam julgamentos de funcionalidade do conhecimento voltados para o mercado de trabalho. Em outros momentos, percebemos que esses julgamentos remetem ao discurso liberal do século XVIII em que a crença em um ideal de sociedade escolarizada e cada vez mais em expansão equacionou letramento a moralidade, prosperidade econômica e virtude cívica (COLLINS; BLOT, 2003).

A transmissão e avaliação dos conteúdos escolares são associadas às cobranças ditadas pelas relações socioeconômicas vigentes na sociedade em que vivemos. Não podemos negá-las: são reais e suportam ações excludentes no mercado de trabalho. Por outro lado, não podemos concordar nem com a concepção bancária (FREIRE, 1983) que subjaz a essa visão de prática educativa nem concordar que ela seja usada como argumento para justificar práticas seletivas e excludentes dentro da escola. Nessa lógica, as possibilidades de futuro dos alunos serão delimitadas pelas regras de seleção e exclusão de nossa sociedade - que nem sempre está comprometida com "um lugar" para todos.

Trata-se de um futuro já-posto: o caráter prescritivo da educação se traduz em uma imagem de futuro que coincide e é regida pelas relações sociais em vigor no presente, como se o conhecimento adquirido na escola fosse a condição necessária e suficiente para garantir uma vida próspera aos alunos.

Se colocarmos em termos de condições necessárias e suficientes para a inclusão social efetiva, certamente a escola tem muito a contribuir. E por que não pensar que aquilo que a escola pode propor é uma condição necessária

"[...] tendo em vista a necessidade de implantação de novas políticas educacionais de várias secretarias de educação do país." Este texto oferece uma visão do processo vivido nas escolas dentro do projeto citado. 
para enfrentar e, quem sabe, eliminar a selvageria dos processos de competição social? Por que não supor uma escola que seja minimamente capaz de oferecer instrumentos diferentes dos ideais liberais?

O discurso que reifica o ideal da pólis excludente entra em conflito com o discurso de mudança defendido pelas medidas da EP, a qual requer a idealização da pólis inclusiva. A idealização ou reificação do modelo social em que vivemos se entrelaçam, assim, à discussão em torno do papel social da escola e do conhecimento nela veiculado, deixando transparecer uma estreita relação entre os conceitos de utopia, letramento e escolarização.

Os dados aqui apresentados foram selecionados dentre vinte e seis gravações em áudio de reuniões em serviço, tendo como critério a discussão das medidas de inclusão pelos educadores. Entendendo "inclusão na escola" como o conjunto de medidas que visam garantir educação a todos os cidadãos a quem o direito à escola foi historicamente denegado, problematizaremos a visão de inclusão social como atribuível ao sucesso ou fracasso escolares, ao poder atribuído aos processos de letramento escolar e ao modelo de sociedade que essas visões requerem. Para isso, revisitarei algumas definições de utopia e apontarei as relações entre letramento, utopia e escolarização para, então, apresentar a análise dos dados.

\section{Utopias}

Harmony and understanding Sympathy and trust abounding No more falsehoods or derisions Golden living dreams of visions Mystic crystal revelation

And the mind's true liberation Aquarius, Aquarius!

Aquarius. Gerome Ragni e James Rado (1979).

Ao revisitarmos o conceito de utopia notamos, inicialmente, a irônica variação dos ideais utópicos de acordo com necessidades, fatos e especificidades contextuais e históricas. Essa afirmação será fundamental para as reflexões que desenvolveremos neste capítulo porque influencia as diferentes definições do conceito de utopia e nutre o debate acadêmico que o posiciona, em sua afirmação ou negação, como um significante fundamental para a reinvenção da democracia moderna. 
Nesse debate, a mentalidade utópica pode ser vista como um estado de incongruência em relação à realidade em que a experiência, o pensamento e a prática orientam-se para objetos que não existem na situação real (MANNHEIM, 1976), ou como uma espécie de sonho social que não leva em conta os passos reais que devem ser dados para a construção de uma nova sociedade (RICOUER, 1989). A mentalidade utópica pode ser vista, ainda, como uma separação do mito da religião. Essa separação é uma das principais características do discurso da modernidade: rompe-se com o ideal de paraíso por meio da imaginação de uma sociedade perfeita produto da ação humana e autorregulada pelos indivíduos que nela vivem (MONTERO, 2001).

Moreira (1997) destaca duas abordagens básicas de utopia: a primeira considera como utopia as descrições detalhadas de alternativas racionais e pragmáticas para as formas existentes de organização social. Essa abordagem aproxima as utopias das grandes narrativas por apresentar dogmática e autoritariamente uma determinada visão de futuro como a certa, como a necessariamente melhor. A segunda abordagem enfatiza a função simbólica das construções utópicas e concebe as utopias não como propostas concretas, mas como possíveis projeções de um tempo ou lugar imaginário, no qual conflitos e contradições podem se confrontar, solucionar, anular, neutralizar ou transformar no contato entre diferentes discursos, nos processos interativos. Nessa perspectiva, utopia é "[...] a exploração de novas possibilidades e vontades humanas, por via da oposição da imaginação à necessidade do que existe, só porque existe em nome de algo radicalmente melhor que a humanidade tem direito de desejar e por que vale a pena lutar." (SANTOS, 1995, p.112).

Na literatura e nas artes, a invenção do futuro modelada por uma imaginação social prospectiva ou por uma escatologia (através de atos de inversão histórica que elegem determinada "Idade do Ouro" como ideal de justiça e perfeição) também nos ajuda a perceber as variações dos ideais utópicos e do próprio conceito de utopia. Para entendermos, por exemplo, a afirmação de Bakhtin (1988b, p. 265)

[...] a escatologia sempre percebe um fim relativamente próximo de modo que o segmento do futuro que o separa do presente desvalorizase, perde o significado e o interesse: é o prolongamento inútil de uma duração indeterminada do presente.

É necessário levarmos em conta o contexto soviético de seu tempo. Porque a ideologia marxista-leninista é, em si mesma, uma forma de pensamento utópico que oficialmente reconheceu toda essa tradição como seu predecessor, a afirmação de Bakhtin parece constituir uma crítica a alguns aspectos da ideologia soviética e uma ênfase antiutópica (MORSON; EMERSON, 1990). 
No entanto, ao mesmo tempo em que as declarações antiutópicas na obra de Bakhtin nos alertam sobre os "perigos utópicos", seus estudos sobre a Carnavalização da literatura dão margem a outra visão de "utopia". Ao enfatizar o impulso emancipatório na voz dos oprimidos e o poder social de transformação que as inversões sociais vividas no curto período de carnaval podem gerar, Bakhtin nos fornece uma alternativa imaginária. A perspectiva carnavalesca é utópica porque abre portas ao desconhecido, à aventura, a um presente que não é reduzido às imagens idealizadas do passado ou do futuro (GARDINER, 1999).

No carnaval, vive-se o início de um mundo de interação e ação dialógica, porque nele a utopia não tem a ambição de criar nem de informar o movimento de transformação social: ela é parte integrante do movimento e se opõe ao monologismo oficial que pretende ser o dono de uma verdade acabada, de uma visão unilateral de sociedade perfeita. As possibilidades são criadas no campo da comunicação dialógica, no campo das trocas interativas cotidianas que edificam a pólis. Utopia é o lugar nenhum, o lugar não definido previamente e em eterno porvir agora. Como um significante utópico, o carnaval não é aquilo que muda, mas o que incita às ações de mudança (OLIVEIRA, 2005). Ele é um chamado à ação. $\mathrm{O}$ utopista é o iniciante de um mundo de interação e ação dialógica.

Para Bakhtin (1997), a utopia pode passar de uma forma monológica a uma forma dialógica. A visão utópica, longe de surgir totalmente pronta da cabeça de um só homem, nasce entre os homens que a procuram juntos no processo de uma troca dialógica. Assim, a utopia já não tem a função de convencer ou de fazer compreender o valor de um modelo ou de uma solução para a questão social. Ela tem como tarefa pôr em marcha o desejo das massas fazer desejar. A utopia deixa de ser um discurso que emana do saber para esclarecer a ignorância (propagado pelos ideais cartesianos) e passa a ser o significante que escancara a porta ao desconhecido, a um futuro verdadeiramente novo, irredutível ao presente ou a um futuro distante. Irredutível às imagens idealizadas no passado.

A perspectiva dialógica rege também o novo espírito utópico defendido por William Morris (2002) em Notícias de lugar-nenhum [1890]. Para pôr em questão o conceito monológico de utopia, Morris propõe, como princípio utópico, a troca de fantasias, um espaço para a liberdade de todas as liberdades. O entendimento de utopia não tem a função de fazer compreender um modelo para a questão social, mas fazer criar modelos e possibilidades. Essa visão se assemelha, ainda, à de Ernst Bloch (1988) que entende utopia como um componente indissociável da condição humana, um desejo contido, uma busca por reconciliação.

Abensur (1990) contribuiu para as reflexões sobre o novo espírito utópico ao apontar alguns de seus traços distintivos. O primeiro traço é a ruptura com a crença na autarquia e na supremacia de uma consciência única para que os cidadãos-utopistas coloquem-se em posição soberana de inventores cotidianos de 
uma ciência social. Outro traço é o princípio da autoemancipação do proletariado e a recusa da "seita utópica" enquanto estrutura autoritária de comunicação e de ação revolucionária. Por fim, o modelo da revolução vinda do alto, que se alimenta do mito do legislador revolucionário, é apontado como aspecto a ser superado na construção de um novo espírito utópico.

Diante dessas considerações, passarei ao trabalho de Souza (2001) para refletir especificamente sobre a variação dos ideais utópicos e suas implicações para os estudos sobre interação, escolarização do conhecimento e letramento. Essas reflexões permitem perceber como o significante utópico e o valor atribuído ao conhecimento por nossa sociedade são elos importantes da cadeia simbólica que gera modalizações discursivas e determinam crenças e ações dos professores.

\section{Utopia, escolarização, letramento}

De acordo com Souza (2001), quatro utopias clássicas despontaram no alvorecer da modernidade. A primeira traduz-se no mito de Cocanha, país imaginário da abundância e do prazer, que retrata a inversão da realidade da Europa Medieval. Nesse período a escassez de alimentos e a fome predominaram para a maior parte da população. Interessante notar que não há indicação de uma organização social ou política do país. Trata-se de um imaginário da fartura que aparece em um conjunto de mitos e lendas, dentre as quais Cocanha se destacava.

A segunda é a Utopia, de Thomas More (1973). De fato, More foi o primeiro a imaginar e a determinar uma organização ideal de sociedade a partir da crítica ao quadro sociopolítico da Inglaterra e de outros países europeus do século XVI. Além da remissão ao desejo de renovação social, moral e política, More cunhou a expressão "utopia", que resulta da fusão do advérbio grego ou=não ao substantivo topos = lugar. "Utopia" é a nação-ilha-cidade imaginária que deu nome ao clássico escrito em 1515.

O insularismo ou isolamento é também característica comum das duas demais idealizações sociais apontadas por Souza (2001): A cidade do sol, de Campanella, escrita na prisão de Nápoles, em 1602, e A nova Atlântida, de Bacon, escrita em Londres, em 1627. Pode-se interpretar esse isolamento das comunidades utópicas como uma forma de proteção de influências nefastas da sociedade real. ${ }^{1}$

\footnotetext{
Essa característica comum às idealizações utópicas - o isolamento para evitar o "contágio de influências nefastas" - foi notada, por inúmeras vezes, em nossas reuniões, como um argumento contra a presença de alunos que não se encaixam nos modelos naturalizados na instituição escolar, principalmente em relação aos alunos que se encontravam em liberdade assistida, ou seja, adolescentes que já cometeram delitos. Os professores referiam-se a eles como aqueles que põem em risco os demais devido à possibilidade de "contágio" moral (ou melhor, imoral). Acredito que a subdivisão de cada série em "classes" por níveis de habilidades, que orienta a enturmação na escola, também pode ser vista como uma ressonância do ideário utópico do insularismo na organização escolar.
} 
Quanto à variação das idealizações, é peculiar à cidade de More o fato de todo utopista dever se dedicar à agricultura por um tempo determinado: uma idealização justificada por contingências econômicas de uma época anterior às transformações da era industrial e uma descrença na capacidade altruísta humana.

Os ideais humanistas fazem da obra de More um dos pilares das reflexões em torno do tema utopia ao levantar questões que ainda se encontram por resolver em nossa sociedade, retratadas em passagens como:

\begin{abstract}
Abandonais os jovens, desde tenra idade, a uma educação ociosa e a um contágio progressivo com o vício; quando chegam à idade adulta, dais-lhes severos castigos, em nome do Senhor, pelos mesmos crimes que impunemente cometem desde a infância. Que fazeis deles senão ladrões, para em seguida os enforcardes? (MORE, 1973, p. 34).
\end{abstract}

Não é esta a mesma lógica que, ainda hoje, produz marginais, justifica a necessidade e rege o funcionamento da justiça em nossa sociedade?

Em A cidade do sol, de Campanella, a idealização se dá na negação da organização familiar como base da sociedade porque essa instituição é responsável pela produção do amor próprio, fonte dos males entre os homens. Nessa obra de Campanella, os habitantes devem trocar de moradia a cada seis meses para não criarem laços amorosos familiares. Essa idealização questionou, sobretudo, os interesses econômicos que determinavam os laços matrimoniais do período em que a obra foi escrita. Além disso, cada cidadão tem o seu lugar e encontra, na sociedade igualitária, as condições para uma boa vida e para o desenvolvimento das virtudes porque ela não é regida pela propriedade privada. Como dito por Campanella (apud SOUZA, 2001, p. 16) em A cidade do sol, todos são, ao mesmo tempo, ricos e pobres: "ricos porque nada lhes falta; pobres pois nada lhes pertence".

Interessante perceber que, apesar da negação da instituição familiar, idealizase a existência e o papel social da instituição escolar:

As crianças, enquanto são de colo, permanecem no quarto das mães. A partir de certa idade, são separadas delas e educadas juntas, em todas as artes e ciências, e no ofício para o qual demonstraram aptidão durante a formação. Meninos e meninas recebem a mesma educação. (SOUZA, 2001, p. 14).

O modelo educacional previsto é semelhante ao regime dos colégios internos e já sugere o papel da escola na organização de uma sociedade. Quanto à questão de gênero, os avanços são significativos se levarmos em conta a discriminação da mulher e o limitado acesso do público feminino ao mundo das letras e do conhecimento socialmente valorizado da época. O livro aponta, ainda, para uma espécie de monarquia universal, acima da qual reinaria o papa. Numa Itália 
dilacerada por grandes divisões internas, o anseio de um governo centralizado se revela na utopia de A cidade do sol (SOUZA, 2001, p. 19).

No entanto, é a versão de Bacon, em A nova Atlântida, que nos permitirá discutir com mais precisão a relação entre letramento, utopia e escolarização, a que nos propomos aqui. Como More e Camponela, Bacon indica, de forma clara, uma organização social e política que tem como fim assegurar o bem-estar terreno dos indivíduos, tal como é o caso das utopias. Apesar de não questionar as instituições políticas nem as relações sociais, o que torna a ilha de Bensalém um modelo de sociedade é a existência de uma instituição chamada Casa de Salomão. Seus membros são encarregados de produzir e difundir as ciências no "reino". O objetivo da instituição é o conhecimento das causas e dos segredos dos movimentos das coisas e a ampliação dos limites do império humano na realização de todas as coisas que forem possíveis. Para isso, dispõem de instrumentos próprios - diríamos que dentre eles a escrita - e lugares apropriados para a investigação sobre todos os ramos do saber - dentre eles a escola -, sobre as artes mecânicas, e sobre os meios de tornar a vida mais cômoda:

\begin{abstract}
Ao que parece, a sociedade da ilha não está sujeita aos ciclos de ascensão e queda das instituições. O que se pode dizer é que na utopia de Bacon está manifesta a idéia do conhecimento como poder organizador da sociedade, a concepção da natureza cooperativa do esforço científico e da orientação das investigações que têm em vista a promoção do bemestar de todos. Trata-se de uma utopia filosófico-científica: as instâncias políticas, econômicas e sociais são subordinadas à instância do saber. (SOUZA, 2001, p. 17-18).
\end{abstract}

Bacon esperava, com o desenvolvimento do saber, o estabelecimento de uma sociedade mais feliz. Sua obra reflete as preocupações da ala radical da Revolução Inglesa na medida em que, por meio de uma postura antiaristotélica, buscava atingir os bispos e o que eles representavam dentro do poder político da monarquia inglesa. Com isso, sua obra atingiria as velhas estruturas, elegendo o conhecimento iluminista como alternativa para a transformação social. O conhecimento passa, então, a ter um poder organizador na sociedade que justifica até hoje - pelo menos em tese - a condição do professor/instrutor no contexto mais geral da divisão social do trabalho (SIGNORINI, 1995b) e fundamenta a crença no poder do conhecimento como possibilidade de ascensão social.

Chamaria a atenção neste ponto porque, em nossa experiência, a crença no poder iluminista como forma de ascensão social, como forma de poder organizador na sociedade perpassa o discurso dos professores e formadores em afirmações como as seguintes: ${ }^{2}$

\footnotetext{
E.= excerto de interação

S. = segmento de interação
} 


\section{E.1}

- A escola plural é excludente na medida que "manda para fora" alunos não aptos, com inúmeras defasagens de conteúdo. Mesmo dentro da escola, o aluno fora de faixa etária é excluído. A inclusão é apenas física...

\section{E.2}

- Sabemos que os saberes são complexos e universais... Como negar isto em uma escola de qualidade?

Note-se, na primeira fala, a afirmação sobre a ineficiência em relação à transmissão de conteúdos ao final do ensino fundamental ("a escola plural [...] manda para fora alunos não aptos [...]") como sinônimo de exclusão, sugerindo que este conteúdo é a garantia de inclusão "lá fora". Na segunda, a representação dos saberes como "complexos e universais" coincide com a ideologia do mito racionalista do letramento na medida em que reafirma a eleição de um saber universal como aquele que garante a escola de qualidade. Esta afirmação diverge dos ideais de uma escola inclusiva, ao desconsiderar as especificidades locais, a valorização da cultura e dos saberes dos alunos e da comunidade em que a escola está inserida.

De fato, o que é cobrado dos alunos no "mundo lá fora", muitas vezes, é o conhecimento escolar. No entanto, vale ressaltar que, ao reproduzir e legitimar apenas determinadas formas de conhecimento, a escola serviu como um dos aparelhos ideológicos do estado (ALTHUSSER, 1983) usados para manter o conhecimento que interessa às formas de produção e consumo, i.e., ao sistema capitalista.

Esses posicionamentos não coincidem com o ideal utópico que defendemos por não estarem abertos às novas formas de conhecimento e aos diálogos entre conhecimentos - diálogos esses construídos em contexto escolar. Divergimos, também, porque reafirmam a necessidade de a escola reproduzir as demandas e o modelo de sociedade excludente que ainda temos.

No entanto, penso que, ao fazerem estas afirmações, os professores não têm o desejo explícito de manter a sociedade como ela é. É importante demonstrar tais situações porque, ao se posicionarem dessa maneira, eles acreditam estar defendendo a inclusão social de seus alunos, já que é assim que o imaginário social está constituído. Importante, pois, percebermos as artimanhas ideológicas do sistema que nos levam a contradições como

$\mathrm{PDE}=$ formadores do Departamento de Educação

P + Iniciais de sua disciplina. Ex.: PMa = Professor de Matemática

/ = pausa breve // = pausa longa

[xxxce] = falas simultâneas incompreensíveis

/.../ = corte na transcrição 
essas e que estão na base da sistematização do conhecimento como forma de poder organizador da sociedade.

Essa sistematização do conhecimento disseminou práticas de leitura e escrita nos diversos contextos que constituem a nossa sociedade grafocêntrica e a habilidade de utilização de tais práticas resulta na ação de "letrar-se", se dermos ao verbo "letrar-se" o sentido de "tornar-se letrado", ou melhor, resulta no conceito de letramento.

Vejamos, então, como esses discursos se apresentam, se entrelaçam e se contradizem em nossos dados.

\section{O poder do conhecimento e as práticas escolares}

A crença no poder do conhecimento foi manifestada nas reuniões de formação em serviço sempre atrelada à possibilidade de ascensão social como podemos constatar no depoimento do professor da Escola 1, em uma das reuniões:

\section{E.3}

- Eu tive muita dificuldade pra estudar. Meu pai era muito rígido. O pessoal pode me taxar de retrógrado porque eu não acredito nessa Escola Plural. Porque quando o indivíduo bater lá na porta eu não vou dar apoio pra ninguém. Não vem me falar que não é com prova que é sim. Depois vai tudo pra rua pedir esmola.

É interessante perceber que o professor não nomeia o sujeito em seu lugar social de "mendigo", mas como "indivíduo", único responsável por seu "destino" e autor de ações previsíveis: "bater à porta", no sentido de pedir ajuda, "ir para a rua", "pedir esmola".

De acordo com o professor, a "prova", instrumento de avaliação, é capaz de impedir que o aluno vá "pra rua pedir esmola". Essa fala reflete o poder organizador do conhecimento e coincide com o mito do letramento como forma de ascensão social e como sinônimo de superioridade cognitiva que não só justifica as pretensas superioridades dos letrados como atribui as falhas da sociedade e do mundo aos iletrados (OLSON, 1997).

Signorini (1995b, p. 162) assim expôs esta visão:

As relações de causa e efeito, assim instituídas, entre poder social e saber escolarizado - o estudado pode (ou consegue) porque sabe; o "não estudado" não pode (ou não consegue) porque não sabe - são de natureza ideológica (STREET, 1984) e estão historicamente relacionadas com o racionalismo iluminista e a universalização da racionalidade científica e tecnológica nas chamadas sociedades ocidentais modernas 
(HABERMAS, 1984). A concepção contemporânea de progresso e de desenvolvimento, freqüentemente associada a taxas de escolarização ou de analfabetismo - é prova disso.

"Ser letrado" é visto como atributo essencial do indivíduo, como requisito ou parte formativa da mentalidade ou modo de pensamento característico de uma época civilizada, quaisquer que sejam as consequências sociais associadas (COLLINS; BLOT, 2003).

Observe-se que a ligação entre letramento e inclusão social na escola subjaz à fala do professor na medida em que, para ele, apenas por meio da assimilação do conhecimento escolar e apenas ao responder aos níveis de avaliação da escola, o aluno pode escapar da miséria das ruas. O professor parece não perceber como a organização racional da escola atua por meio de um currículo oculto que contribui com regras determinantes para a ação pessoal e social dos alunos. Consciente e inconscientemente, formal e informalmente, a organização das relações trabalhistas e sociais estrutura o microcosmo da escola. Dessa forma, a escola reifica a sua assimilação junto à comunidade escolar.

Assim, as bases morais e sociais do letramento ganham reforço diretamente do ambiente construído para transmiti-las (GRAFF, 1995). A maior consequência é, sem dúvida, a incitação à impotência e passividade política. Essa ideologia é subjacente ao modelo funcional de letramento em que o objetivo maior é o de servir aos interesses da elite à custa dos interesses dos subordinados. Com isso, são gerados sentimentos no próprio jogo que é praticado no processo de aprendizagem das regras, habilidades, crenças e valores que são divulgados como necessários à participação das forças hegemônicas da sociedade. Nesse sentido, diante de referências às bases morais e sociais do letramento, conforme exposto na fala de PMa, estamos também diante de relações estabelecidas entre letramento, inclusão social e as formas de idealização social.

Assim como em A nova Atlântica, de Bacon, o conhecimento em nossa sociedade tem um poder organizador. A escola, que aqui comparamos à "Casa de Salomão", é uma das principais instituições responsáveis pela mediação e disseminação desse poder. Isso faz do processo de escolarização um processo político e um significante utópico, na medida em que é determinante não só em seu tempo presente, mas principalmente para as possibilidades de um "futuro melhor" dos alunos. As práticas de letramento escolar são condição para o desempenho dos futuros agentes sociais. Graff $(1995$, p. 86) nos mostra as raízes históricas desse pensamento:

Uma das suposições centrais das muitas de nosso conjunto, herdada de relações letramento/sociedade é a de juntar letramento com desenvolvimento econômico e trabalho. Toda uma escola de pensamento econômico, a assim chamada teoria do "capital humano" 
iniciada por Becker e Shultz, tem suas raízes nesse preceito que foi proeminente na teoria e nas táticas de modernização. O principal problema para o desenvolvimento econômico é a doutrinação da força do trabalho... Professores não conseguem entender que com isso só conseguem contribuir para a instrução de uma dimensão disciplinar. $\mathrm{O}$ mercado de trabalho não quer uma educação para ler e escrever, mas comportamentos e valores exigidos para industrialização, produtividade e hábitos socialmente aprovados. A escolarização constitui então um treinamento em ser treinado.

Concordamos com as afirmações de Graff na medida em que questiona o uso da dimensão disciplinar como instrumento determinante na formação de corpos dóceis, de alunos alienados e sem senso crítico. Essas práticas disciplinares são utilizadas para garantir apenas o ensinamento do conhecimento legitimado pela elite econômica.

Não esqueceremos, contudo, que "ensinar e aprender" envolve o desenvolvimento de habilidades (como a leitura e a escrita) em que a disciplina é fundamental. Entendemos disciplina como um comportamento necessário à troca, transmissão ou construção de conhecimentos. Comportar-se de forma disciplinada é garantir momentos em que a atenção dos sujeitos estará focada no processo de construção de um conhecimento significativo. A dimensão política funda as escolhas curriculares.

O significado político do letramento tem a ver com as formas que ele assume e com o papel que ele exerce no processo de idealização de uma sociedade democrática. As práticas de letramento escolar são, antes de tudo, armas contra (ou a favor) da opressão. Professores politicamente comprometidos criam espaços na educação formal para fazer da educação uma prática de liberdade porque acreditam ser esta a tarefa mais importante da escola. O mesmo contexto social que foi utilizado para fazer da aprendizagem da escrita uma forma de escravização (OLSON, 1997) passa a ser um contexto subversivo e libertário (FREIRE, 1983).

Não pretendo, de forma alguma, negar o poder social do conhecimento em nossa sociedade. Ele é real. Escolarização e letramento são fatores importantes na busca de metas humanas na sociedade moderna. Pelo contrário, ao apontarmos as relações entre utopia, letramento e inclusão na fala dos professores, estamos, de certa forma, desvendando este poder. Porém, o entendimento sobre o que letramento e escolarização sejam e como e com que alcance podem contribuir para a construção de uma sociedade melhor torna-se questionável na medida em que as relações estruturais de poder desigual na sociedade não são reconhecidas como consequências históricas estabelecidas pelos cidadãos que edificam e sustentam a pólis em que vivem, ou melhor, consequências de como humanos organizaram suas vidas sociais. Torna-se questionável, ainda, porque, sem o 
reconhecimento do papel político, os professores tendem a firmar as desigualdades e práticas excludentes na escola em nome desse "poder" social do conhecimento.

Este talvez seja o maior risco na crença e reprodução de um ideal iluminista racionalista: tomar o já-estabelecido como ideal e não o questionamento e a construção de relações sociais diferenciadas e mais justas. O que não quer dizer que os professores que defendem este ideal de escola não sonhem ou que o ideal racionalista não atue como um significante utópico: o que os dados nos levam a crer é que eles sonham e idealizam a sociedade sem perceber as contradições sociais que defendem a partir da manutenção dos ideais liberais e capitalistas que fundamentam o mito racionalista de letramento e que não coincidem com o ideal dialógico sempre-em-construção que defendemos para uma escola inclusiva.

Parece-me que se tornou inerente ao entendimento de letramento e escolarização uma confusão entre a visão prescritivista de letramento - como uma afirmação de valores e usos do conhecimento -, e uma visão descritivista de letramento - como habilidades cognitivas promovidas e acessíveis apenas por meio da escola, conforme já demonstramos neste texto.

No excerto de interação abaixo, as relações de causa e efeito entre saber escolarizado e inclusão social de alunos de classes desprivilegiadas ficaram evidentes. Nessa reunião, a equipe de formadores foi chamada à escola para discutir os critérios da ficha de avaliação dos alunos. Na verdade, nesta época, as fichas de avaliação eram feitas pelas escolas, mas dependiam da aprovação da equipe pedagógica do departamento de educação. A fiscalização e aprovação do modelo de fichas avaliativas era um mecanismo de controle burocrático, criado na implementação da EP como forma de garantir a discussão de uma das ações que sempre permaneceu como a mais polêmica dentre as implementadas pela EP - a avaliação. Neste momento eles discutem questões relacionadas ao relacionamento dos alunos e, logo a seguir, aflora a discussão sobre a EP:

\section{S1. Escola 1}

PAr - ...E cê vê que é despreparo deles [dos alunos], de conhecimento até mesmo de vivência/.../ E isto deixa a gente assim... Por mais que a gente tente aproximar...

$\mathrm{PDE}-\mathrm{E}$ isto é por causa desta outra cultura que a gente tem pra oferecer. Isto aí já tá mais que claro/.../ que a gente parta do conhecimento deles pra um diálogo com o que a gente quer, né?

PA - Pois é, mas o que eu fico pensando é que o que é mais complicado para o professor é que ele tem uma formação " $\mathrm{x}$ " e tem que reduzir a "y" para atender a uma escola sem estrutura. Eu acho que aí já começa a ultrapassar os limites do professor/.../ Eu entro na sala e vejo o aluno, eu tenho vontade de acordar ele. Estes meninos aqui... eles não têm vontade. Eles não pensam em nada não. É assim 
eles... eles não sonham não. O máximo que eles querem é casar e ter filhos... não pensam no mundo aí fora, não... vão ficando por aqui... A vontade nossa é de fazer isto também acordar eles /... / Porque a Escola Plural é ainda mais excludente. Não dá pra negar que nós temos uma formação/ poxa/ que nós fomos educados e eu não estou preparada para lidar com este tipo de aluno de uma escola sem estrutura. É uma questão de estrutura...//.

$\mathrm{PDE}-/ .$. / Eu tenho pensado muito nesta questão que tem sido constantemente colocada/ né/ de que os alunos estão simplesmente passando/ e que estão sendo/ no final das contas/ excluídos da mesma forma/ e// e isto// é realmente muito angustiante/ Serve pra gente tá pensando: que Escola Plural foi construída até aqui/ em cinco anos?/ sem culpa/ né?/ Sem dizer que a culpa é do professor/ é do aluno/ é da EP que não dá bomba/ Mas/ assim/ a certeza da necessidade da gente tá repensando nossa prática/ até minha mesmo/ neste lugar que eu estou ocupando nesta rede agora. Isto tem que ficar muito claro mesmo, a gente tem que tá dialogando. E como que é este desafio nosso de estar construindo uma escola inclusiva dentro de uma sociedade que cada vez mais exclui/ que cada dia mais cobra/ Mas aonde é que eu vou estar me inserindo nisso aí?// A mudança vai vir é lá de fora ou é da minha ação?/.../ Aonde é que eu vou tá assinando embaixo?// Quando cê fala, professora/ que você aprova o "Provão"/ e a escola aqui ela tem autonomia pra tá dando o provão/ ou não/ o que que a gente estaria condenando na idéia de "Provão"?// É exatamente o que exclui/ o que seleciona/ o que vem cobrar conhecimentos historicamente legitimados/ é o que exclui a cultura dos alunos.// Eu não tenho nada contra o "Provão"// Agora se ele exclui/ se ele vem é reforçar uma política de exclusão que tem mais de duzentos anos/ ele vai ser colocado em questão sim....// Ele vai tá realmente é ajudando o menino a abrir/ é a buscar a vida/ é a buscar o ser humano enquanto uma pessoa que tem um mundo enorme de possibilidades na frente dele/ ou é / realmente / a inculcar a competição?// É esta sociedade que a gente tá construindo?/.../ Então se a gente não sonhar um pouquinho/ me desculpem// Nesta profissão nossa que a gente não tem dinheiro, que é complicada uma formação, como você acabou de dizer...

PA - [Que exclui o próprio professor...]

PER - Que exclui o professor também, né?/...? Então assim, o nosso material é o humano. Ele não é um material pra marcar cruzinha.

A imagem que PA tem de seus alunos - "despreparados" a ponto de ter que reduzir o seu conhecimento acadêmico a "y" porque os alunos não conseguiriam aprender, ou ainda alunos que não têm vontade ou que não sonham com "o mundo aí fora" - é influenciada pelo mito de "esclarecer o ignorante" para uma "sociedade iluminada" (SIGNORINI, 1995a), presente em sua fala principalmente por meio da metáfora do adormecido ("PA - Eu entro na sala e vejo o aluno, eu tenho vontade de acordar ele."). 
Como no modelo autônomo de letramento descrito por Street (1984), em que a construção de conhecimento se dá de forma descontextualizada, essa visão de PA desconsidera os conhecimentos do educando ("...E cê vê que é despreparo deles, de conhecimento até mesmo de vivência"), deixando transparecer uma imagem de aluno tabula rasa. Centrada em seu próprio universo sócio-cultural e econômico, a professora acredita que "eles não sonham não", que devem ser "acordados", porque as ambições deles (que, segundo ela, se "restringem" a casar e ter filhos) não são as do "mundo aí fora". Nesse sentido ela parece concordar com a sociedade conforme ela é. A relação estabelecida por ela entre o despreparo dos alunos em relação às práticas de letramento escolar e o fato de os alunos "não sonharem" nos coloca a pergunta: será que na visão da professora eles não sonham com ascensão social porque eles não satisfazem o seu ideal de aluno? Novamente, o que percebemos é que a condição para "acordar os alunos" parece ser a incorporação da sua cultura, seu saber que tem "o" poder organizador na sociedade.

Esta é a visão das utopias totais e monológicas, a visão dos valores iluministas como um otimismo secular (baseado na sociedade europeia pósfeudal) e como um desejo racional de conter o mundo em um todo homogêneo, de impor uma ordem e de excluir a diversidade e a diferença (GARDINER, 1999). Reafirmamos: não queremos dizer que não há um significante utópico dentro deste posicionamento. Apenas questionamos a forma como este significante tem se imposto por meio de discursos e contradições ideológicas. Algo parecido com a afirmação de Marx e Engels em Manifesto comunista sobre o "socialismo conservador" ou "burguês":

Os burgueses socialistas gostariam de conservar as condições de existência da sociedade moderna, mas sem as lutas e os perigos que decorrem necessariamente dela. Querem conservar a sociedade existente, mas sem os elementos que a perturbam e a dissolvem.

Querem a burguesia sem o proletariado. (MARX; ENGELS apud ABENSUR, 1990, p. 52, grifo nosso).

Ou, no nosso caso, querem a escola sem a diversidade cultural que os alunos de classes economicamente desfavorecidas a ela impõem.

Diante desse segmento, faz-se necessário apontar um desdobramento dos dois modelos de Street (1984). De fato, PA se aproxima do modelo autônomo de letramento por não reconhecer o horizonte sócio-cultural dos alunos. No entanto, ela não se restringe ao "não reconhecimento". Seu posicionamento se diferencia desse modelo porque sua visão não é simplesmente descontextualizada: ela reconhece e privilegia apenas o valor de seu próprio mundo cultural. Com isso, nega qualquer possibilidade de aceitação do segundo modelo de Street, o modelo de letramento ideológico, que pressupõe o reconhecimento do conceito de 
letramento como um processo dinâmico em que a cultura canônica interage com a cultura popular (STREET, 1984).

Suas falas nos levam a crer que, em sua visão, o letramento escolar apenas ajudará o aluno a se curvar diante das regras excludentes e da ideologia competitiva do mercado de trabalho. Com isso, ela afirma o modelo de sociedade em que vivemos e nos coloca diante de um modelo que aqui chamamos de letramento ideológico excludente, regido por crenças e ideologias que historicamente garantem a reprodução de valores, conhecimentos, linguagens, enfim, da cultura das classes economicamente favorecidas.

Essas afirmações podem sugerir uma visão de letramento fundada em um marxismo por demais ortodoxo, que não me parece, de forma alguma, a única ou a melhor alternativa ideológica. Ao questionar a hegemonia da cultura das elites e o papel que exerce no currículo canônico tradicional não estou propondo que o mesmo seja banido, mas que haja um diálogo entre culturas, entre linguagens e visões de mundo. Além disso, seria inocência acreditar que os responsáveis pelo processo escolar nas escolas públicas hoje sejam membros da classe dominante. Professores que correm periferias dos grandes centros e das cidades do interior do Brasil há tempos vêm vivendo o processo de proletarização de sua profissão. Então, as possibilidades de transformação dessa cultura escolar são enormes, até mesmo pela ausência de uma sistemática contínua de formação de professores.

A visão de PAr difere-se, ainda, do mito do letramento como sinônimo de progresso social (OLSON, 1997) porque não há a pressuposição de que os alunos letrados construirão uma sociedade melhor. Eles se adequarão às regras da sociedade que já está posta. O letramento escolar servirá, portanto, para moldálos a essa sociedade.

Sua visão é excludente e antiutópica em dois sentidos:

- em relação ao aluno, ela afirma sua "vontade de acordá-lo" como algo que não se concretizará já que "eles não têm vontade de acordar";

- ela não acredita em um outro modelo de sociedade em que a inclusão de todos seja direito de cada cidadão. A apropriação do conhecimento é necessária para que eles sejam incluídos na sociedade competitiva e excludente em que (ainda) vivemos, e não para a construção de uma sociedade igualitária.

Em parte, PA tem razão: o letramento é um dos fatores necessários à inclusão no mercado de trabalho porque vivemos em uma sociedade letrada. Mas não é o fator determinístico e nem é sinônimo de Inclusão Social, como a idealizamos aqui. O processo de inclusão que defendemos vai além da aquisição de um emprego. Uma sociedade inclusiva é, antes de mais nada, aquela que respeita a subjetividade de cada ser humano. Nela, o letramento não é nem causa nem consequência 
determinante do processo de formação e desempenho das identidades sociais. Esse processo é, antes, mediado pelo letramento (COLLINS; BLOT, 2003).

PAr tem razão, ainda, ao reclamar sobre a falta de estrutura de nosso sistema educacional, que muitas vezes "exclui o próprio professor". Os fatores que determinam o baixo alcance do letramento escolar já eram apontados por Graff (1979): condições físicas, superpopulação das salas de aula, poucas oportunidades de formação dos professores, baixos salários, etc.

Não podemos descartar de todo a avaliação que PAr faz do processo. Ela pode não ter o domínio categorial para ajustar a sua fala aos fatos que transcorrem na escola como gostaríamos que ela tivesse. Mas não podemos ignorar ou recusar essa sensação imediata, até irrefletida, que ela tem do processo escolar. Isso é real, não há como negá-lo. Se o poder institucional quiser contar com os professores para um devir utópico, ouvi-los é o ponto de partida.

Indo um pouco além de sua leitura diríamos que, como estamos diante de um programa político-pedagógico de inclusão, além da "infraestrutura" das medidas compulsórias de inclusão e da parceria entre as secretarias do município, a "superestrutura", as concepções ideológicas dos sujeitos envolvidos são determinantes para sua realização. Como dito por PDE: "Mas aonde é que eu vou estar me inserindo nisso aí?// A mudança vai vir é lá de fora ou é da minha ação?/.../ Aonde é que eu vou tá assinando embaixo?".

Sua resposta aponta para uma alternativa dialógica de construção de conhecimento ("que a gente parta do conhecimento deles pra um diálogo com o que a gente quer, né?"), como exemplificado pelo trabalho de Freire (1983). Sua consideração de que o aluno possui conhecimentos é, sem dúvida, uma précondição para a implementação de práticas de letramento inclusivas.

PDE questiona a prática do provão adotada na escola como forma de levar PA a perceber que a dimensão ideológica que determina nossas ações é tão importante quanto a infraestrutura necessária à viabilização de um projeto de educação inclusiva. Sua fala refere, ainda, à importância do significante utópico para o bom andamento do projeto ("Então se a gente não sonhar um pouquinho/ me desculpem// Nesta profissão nossa que a gente não tem dinheiro, que é complicada uma formação, como você acabou de dizer...").

Na verdade, a importância do significante utópico como força que move a construção da pólis inclusiva foi uma das muitas lições que aprendi com os professores durante as reuniões:

E.4.

- ...olha, e a gente pode deixá-los [os alunos] lá sozinhos fazendo a prova que eles não colam /.../ eu só queria eh, se você pegar os cem anos de 
história aí/ a classe baixa não tinha acesso à escola de forma nenhuma, né?// Depois ela teve acesso à escola, mas era excluída. Foi um passo, né? Agora ela tem acesso, não é excluída, mas não garante o acesso ao conhecimento. Eu acho que este é o próximo passo, né? /.../ele estar na escola, eu acho que foi um grande passo para a não exclusão. Agora o próximo passo é garantir o acesso.

A perspectiva histórica do professor reforça nossa crença na importância do significante utópico para um projeto de inclusão na escola. Sua leitura vem ao encontro das diferenciações entre direito a vaga, acesso e inclusão. Primeiramente, o professor relata estar vivendo uma experiência em que a relação com o conhecimento não é mais pautada pela mediação de notas (".. $.0 l h a$, e a gente pode deixá-los lá sozinhos fazendo a prova que eles não colam"). A seguir, a idealização de um próximo passo a ser dado e a crença que podemos dar esse passo se acreditarmos e se buscarmos ações que garantam a apropriação do conhecimento exemplificam o significante utópico que move a construção da pólis inclusiva. ("Agora ela tem acesso, não é excluída, mas não garante o acesso ao conhecimento. Eu acho que este é o próximo passo, né?").

\section{Considerações finais}

Ao nos voltarmos para as interações entre professores e formadores da RME-BH com o interesse de discutir as relações entre práticas escolares, utopia e inclusão social, deparamo-nos com a dimensão política do ofício "professor" e notamos como a vida cívica depende do poder da palavra. Os diferentes pontos de vista dos cidadãos entram em contato nos processos interativos, garantindo a vitalidade necessária à luta entre as partes da pólis - já que ela, ainda, é constituída por "partes", ou classes, se assim preferirmos nomear). De fato, a vitalidade da luta pode ser capaz de criar novos e ressignificar velhos conceitos.

As interações apresentadas neste artigo nos levam a crer que a perspectiva utópica dialógica é um processo em andamento na RME-BH. É por meio da exposição de visões e idealizações conflitantes, ou melhor, por meio do debate político e ideológico desencadeado pela EP, que as trocas interativas e a negociação de significados podem se concretizar em uma pólis inclusiva. Estamos, ainda, muito aquém de nossas idealizações de uma escola crítica inclusiva, mas o ressignificar do valor das práticas de letramento e do papel social da escola faz parte da consecução dessas idealizações.

O resultado é, na maioria das vezes, uma mistura de novas e velhas convenções. Na verdade, há uma contínua interação e mudança. Por isso, compartilhar experiências na escola é possível a partir de determinadas práxis que requerem reflexão e ação política. 
Enquanto professores, podemos criar (ou não) oportunidades de uso efetivo de práticas inclusivas e, também, criar (ou não) mecanismos institucionais que garantam que as vozes dos grupos excluídos socialmente sejam ouvidas, tomadas seriamente e transformadas em ações. O processo de letramento escolar pode ser, em si mesmo, uma alternativa utópica a desafiar uma sociedade excludente. As linguagens usadas e os meios letrados empregados, os textos lidos e produzidos nos dizem muito da construção e transformação de subjetividades por meio de práticas de letramento. Essas subjetividades não são "formadas" pelo letramento; mas o forjar, tanto social como pessoal, das "novas" identidades híbridas ocorre em um caldeirão de culturas em que o letramento é ao mesmo tempo uma arma e um escudo.

OLIVEIRA, M. G. de. Interaction, utopia and the construction of inclusive schools. Alfa, São Paulo, v.58, n.3, p.571-591, 2014.

- ABSTRACT: In this article, we resumed the advent of the school in the cradle of western capitalist society and the role of the reading and writing in the idealization of a perfect society, based on the concepts of utopia (MANNHEIM, 1976; RICOEUR, 1989; BAKHTIN, 1988, 1997; SANTOS: 1995; OLIVEIRA, 2005) and literacy (STREET, 2003; SIGNORINI, 1995; SOARES, 1998; COLLINS; BLOT, 2003). Our goal is to revisit these concepts in order to analyze interactions between teachers and teacher educators who experience changes implemented by Escola Plural Program policies, ongoing since 1994, in Belo Horizonte, Brazil. Understanding "inclusion in school" as a set of measures to ensure education to ALL citizens to whom this right has historically been denied, we cut out fragments of interactions that occurred during training meetings. The analysis show that our subjects sometimes reproduce, sometimes resist liberal discourse and the 'outside world', as they refer to social relations. They also reveal the relations between the vision of society and inclusive measures and how teachers perceive the role of schooling in the future life of the students and how they idealize (or not) all this process.

- KEYWORDS: Interaction. Utopia. Inclusive schools.

\section{REFERÊNCIAS}

ABENSUR, M. O novo espírito utópico. Tradução de Urias Arantes et al. Campinas: Ed. da UNICAMP, 1990.

ALTHUSSER, L. Aparelhos ideológicos de Estado. Tradução de Maia L. V. Castro. Rio de Janeiro: Graal, 1983.

ARENDT, H. A condição humana. Petrópolis: Vozes, 1988.

BAKHTIN, M. Problemas da poética de Dostoievski. Tradução de Paulo Bezerra. Rio de Janeiro: Forense Universitária, 1997. 
O discurso no romance. In: Questões de literatura e de estética: a teoria do romance. Tradução de Aurora F. Bernadini. São Paulo: Hucitec, 1988a. p.71-210.

Formas de tempo e de cronotopo no romance: ensaios de poética histórica. In: Questões de literatura e de estética: a teoria do romance. Tradução de Aurora F. Bernadini. São Paulo: Hucitec, 1988b. p. 211-362.

BLOCH, E. The utopian function of art and literature: selected essays. studies in contemporary German social thought. Cambridge: MIT, 1988.

COLLINS, J.; BLOT, R. Literacy and literacies: texts, power and identity. Cambridge: Cambridge University Press, 2003.

FRADE, I. C. A. S.; SILVA, C. S. R. A leitura de textos oficiais: uma questão plural. In: MARINHO, M.; SILVA, C. S. R. (Org.). Leituras do professor. Campinas: Mercado de Letras, 1998. p. 93-117.

FREIRE, P. Educação como prática da liberdade. Rio de Janeiro: Paz e Terra, 1983.

GARDINER, M. Bakhtin's Carnival: topia as critique. In: EMERSON, C. Critical essays on Mikhail Bakhtin. New York: G. K. Hall, 1999. p. 37-56.

GRAFF, H. Os labirintos do letramento. Porto Alegre: Artes Médicas, 1995.

The literacy myth: literacy and social structure in the nineteenthcentury city. New York: New York Academic Press, 1979.

HABERMAS, J. The theory of communicative action. Tradução de Thomas McCarthy. Boston: Beacon Press, 1984.

MANNHEIM, K. Ideologia e utopia. Rio de Janeiro: Jorge Zahar, 1976.

MONTERO, P. Utopias missionárias na América. Revista Sexta Feira, São Paulo, n. 6, p.54-79, 2001.

MORE,T. Utopia. Tradução de Maria Isabel G. Tomaz. Lisboa: Publicações Europa América, 1973.

MOREIRA, A. F. B. Currículo, utopia e pós-modernidade. In: MOREIRA, A. F. B. (Org.). Currículo, questões atuais. Campinas: Papirus, 1997. p. 9-28.

MORRIS, W. Notícias de lugar nenhum ou uma época de tranqüilidade. São Paulo: Fundação Perseu Abramo, 2002.

MORSON, G. S.; EMERSON, C. Mikhail Bakhtin: creation of a prosaics. Stanford: Stanford University Press, 1990. 
OLIVEIRA, M. G. Shakespeare no subúrbio: o carnaval na literatura e na aula de leitura. Trabalhos em Lingüística Aplicada, Campinas, v. 44, n. 1, p. 97-113, jan./jun. 2005.

OLSON, D. O mundo no papel. Tradução de Sérgio Bath. São Paulo: Ática, 1997. RAGNI, G.; RADO, J. Aquarius. Intérprete: Ren Woods. In: HAIR: original soundtrack. [S.1.]: RCA, 1979. 1 disco sonoro. Lado A, Faixa 1.

RICOEUR, P. Ideologia y utopia. Barcelona: Gedisa, 1989.

SANTOS, B. S. Pela mão de Alice: o social e o político na pós-modernidade. Lisboa: Afrontamento, 1995.

SIGNORINI, I. "Esclarecer o ignorante": a concepção escolarizada do acesso ao mundo da escrita. ESP, São Paulo, v. 15, n. 1 e 2, p. 163-171, 1995 a.

Letramento e inflexibilidade comunicativa. In: KLEIMAN, A. B. Os significados do letramento: uma perspectiva sobre a prática social da escrita. São Paulo: Mercado de Letras, 1995b. p.156-171.

SOARES, M. Letramento: um tema em três gêneros. Belo Horizonte: Autêntica, 1998.

SOUZA, M. G. O real e seu avesso: as utopias clássicas. Revista Sexta Feira, São Paulo, n.6, p.12-22, 2001.

STREET, B. V. What's "new" in New Literacy Studies? critical approaches to literacy in theory and practice. Current Issues in Comparative Education, v.5, n.2, p.77-91, 2003.

Literacy in theory and practice. Cambridge: CUP, 1984.

\section{Bibliografia consultada}

BAKHTIN, M. A cultura popular na Idade Média e no Renascimento. Tradução de Yara Frateschi. São Paulo: Hucitec, 1993.

Marxismo e filosofia da linguagem. Tradução de Michel Lahud e Yara F. Vieira. São Paulo: Hucitec, 1992.

BOURDIEU, P. La distincion: criterios y bases sociales del gusto. Madri:Taurus Humanidades, 2002.

OLIVEIRA, M. G. de. O professor e a pólis: antigas crenças, velhos conceitos, novas concepturalizações. Revista Intercâmbio, São Paulo, v. XV, p. 286-296, 2006.

Recebido em março de 2013.

Aprovado em outubro de 2013. 
